\title{
Notification List Notification that new names and new combinations
have appeared in volume 60 , part 11 , of the IJSEM
}

Correspondence

Jean Euzéby

email address can be found at www.bacterio.net
This listing of names published in a previous issue of the IJSEM is provided as a service to bacteriology to assist in the recognition of new names and new combinations. This procedure was proposed by the Judicial Commission [Minute 11(ii), Int J Syst Bacteriol 41 (1991), p. 185]. The names given herein are listed according to the Rules of priority (i.e. page number and order of valid publication of names in the original articles). Taxonomic opinions included in this List (i.e. the creation of synonyms or the emendation of circumscriptions) cannot be considered as validly published nor, in any other way, approved by the International Committee on Systematics of Prokaryotes and its Judicial Commission.

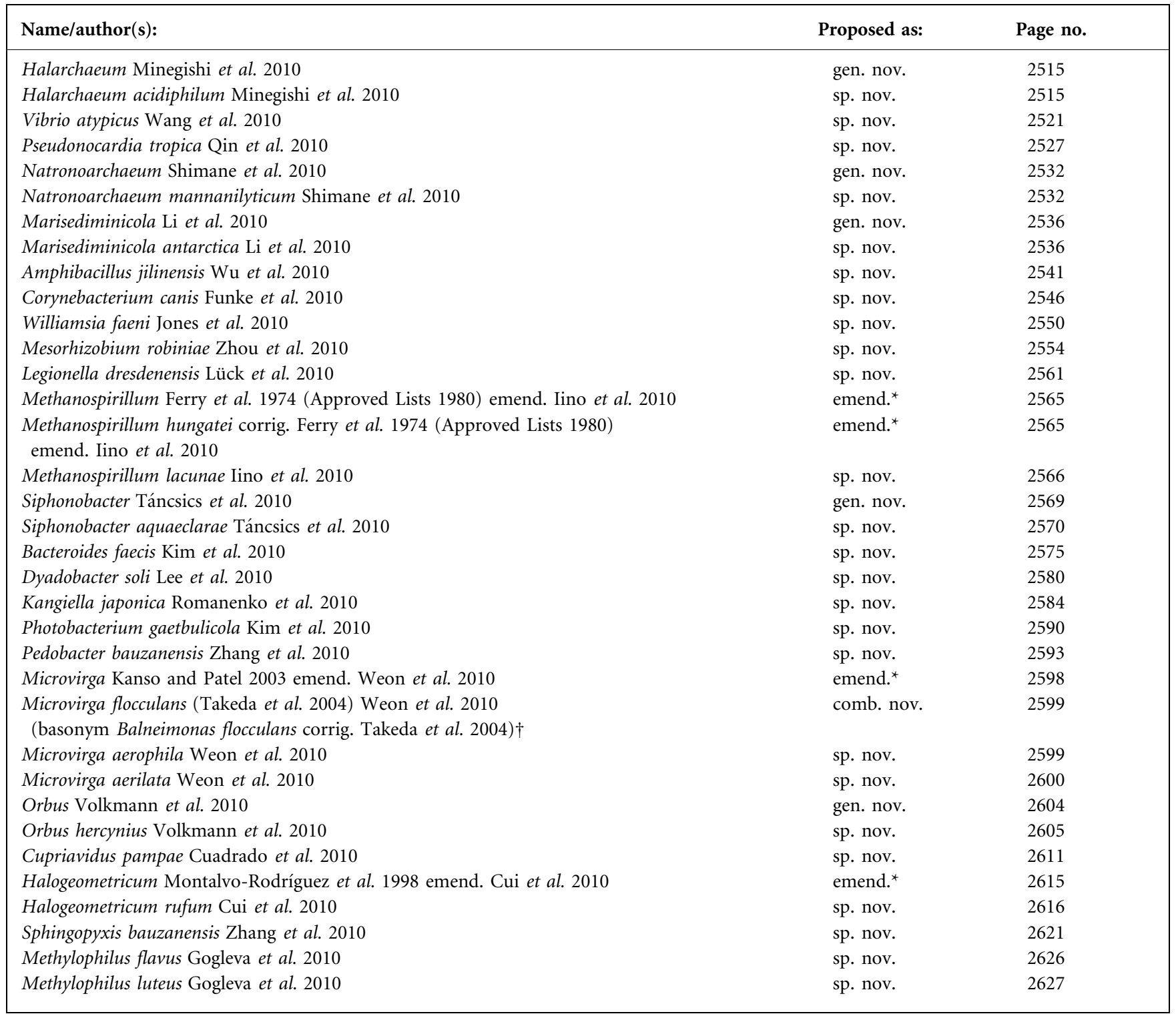


cont.

\begin{tabular}{|c|c|c|}
\hline Name/author(s): & Proposed as: & Page no. \\
\hline Amycolatopsis helveola Tamura et al. 2010 & sp. nov. & 2631 \\
\hline Amycolatopsis pigmentata Tamura et al. 2010 & sp. nov. & 2632 \\
\hline Microbacterium lindanitolerans Lal et al. 2010 & sp. nov. & 2637 \\
\hline Slackia Wade et al. 1999 emend. Nagai et al. 2010 & emend.* & 2643 \\
\hline Slackia piriformis Nagai et al. 2010 & sp. nov. & 2643 \\
\hline Collinsella tanakaei Nagai et al. 2010 & sp. nov. & 2643 \\
\hline Actinomadura scrupuli Lee and Lee 2010 & sp. nov. & 2649 \\
\hline Phytohabitans Inahashi et al. 2010 & gen. nov. & 2656 \\
\hline Phytohabitans suffuscus Inahashi et al. 2010 & sp. nov. & 2656 \\
\hline Methylocapsa Dedysh et al. 2002 emend. Dunfield et al. 2010 & emend.* & 2663 \\
\hline Methylocapsa aurea Dunfield et al. 2010 & sp. nov. & 2664 \\
\hline Microbacterium radiodurans Zhang et al. 2010 & sp. nov. & 2668 \\
\hline
\end{tabular}

${ }^{*}$ Taxonomic opinion.

$\dagger$ Note: Weon et al. 2010 propose to transfer Balneimonas flocculans corrig. Takeda et al. 2004 (the type species of the genus Balneimonas) to the genus Microvirga Kanso and Patel 2003 as Microvirga flocculans (Takeda et al. 2004) Weon et al. 2010 comb. nov. According to Rule 37a, bacteriologists adhering to this proposal must change the name Balneimonas Takeda et al. 2004 to Microvirga Kanso and Patel 2003. 